University of Nebraska - Lincoln

DigitalCommons@University of Nebraska - Lincoln

1996

Costs and Benefits of Monogamy and Polygyny for Yanomamö Women

Raymond B. Hames

University of Nebraska-Lincoln, rhames2@unl.edu

Follow this and additional works at: https://digitalcommons.unl.edu/anthropologyfacpub

Part of the Biological and Physical Anthropology Commons, and the Social and Cultural Anthropology Commons

Hames, Raymond B., "Costs and Benefits of Monogamy and Polygyny for Yanomamö Women" (1996). Anthropology Faculty Publications. 53.

https://digitalcommons.unl.edu/anthropologyfacpub/53

This Article is brought to you for free and open access by the Anthropology, Department of at DigitalCommons@University of Nebraska - Lincoln. It has been accepted for inclusion in Anthropology Faculty Publications by an authorized administrator of DigitalCommons@University of Nebraska - Lincoln. 


\title{
Costs and Benefits of Monogamy and Polygyny for Yanomamö Women
}

\author{
Raymond Hames \\ Department of Anthropology, University of Nebraska-Lincoln, Lincoln, NE 68588, USA \\ email rhames@unl.edu
}

In this paper I analyze some of the economic costs and benefits of monogamy and polygyny for Yanomamö women. The evolutionary ecological model of resource defense polygyny predicts that when female choice is operative females will choose those males who control resources that will maximize a female's reproductive success. A female will choose a polygynous strategy (i.e., become a co-wife) if a currently married male has more resources to offer than other unmarried males or monogamous males. This model has been successfully used to predict polygynous mating in tribal societies where males are stratified in terms of their ownership or control of land, cattle, or other wealth-producing resources (Borgerhoff Mulder 1985, 1987) and in state-level societies with extreme economic stratification (Betzig 1986). Not considered in these models are the large group of societies in which polygyny exists but where males are not differentiated in terms of wealth- or resource-holding ability. The subject of this analysis, The Yanomamö Indians of Venezuela occupying drainages south of the upper Orinoco River, have a moderate rate of polygyny (e.g., approximately $25 \%$ of all married men in my sample are married polygynously), yet ownership of land, domesticated animals, or other wealth-producing resources is absent. Potentially, this means that polygynous women may be at an economic disadvantage because they, in effect, must share the economic resources of a husband who has no more wealth than a monogamous husband. In this report I seek to determine some of the economic costs and benefits of being a polygynously married woman. The analysis focuses on the economic factors that potentially differentiate polygynous and monogamous households in terms of size of gardens, labor time of husbands and wives, and the flows of critical food resources to households. I find that the only statistically significant factor that differentiates monogamous households from polygynous households is that the latter receive more food resources from other households than the former. I conclude by suggesting that polygynous women avoid the potential costs of polygyny because they are economically subsidized by other households in the village owing to the high social status of their husbands. 


\section{Theoretical Issues}

Recent cross-cultural and intracultural research on the causes of polygyny indicate that either economic or social structural factors (warfare and fraternal interest groups) are associated with polygyny (White and Burton 1988: 882-884). The association between male wealth and polygyny was first demonstrated crossculturally by Murdock (1949). Borgerhoff Mulder (1988), following Hartung's (1982) cross-cultural survey (see also Grossbard 1976, 1980), clearly demonstrates that wealthy Kipsigis men are more likely to be polygynists (Borgerhoff Mulder, 1985, 1987). White (1988) reverses the causal arrow by arguing that women's labor creates wealth that men use to acquire more wives (see also Boserup 1970). Finally, Grossbard (1980) shows that polygyny may also occur when co-wives work together to create economies of scale.

In a recent cross-cultural study White (1988) encountered two general patterns of polygyny, which he classified as wealth-increasing and sororal. What he called wealth-increasing polygyny is associated with warfare and the presence of fraternal interest groups. Where warfare and wife capture occur, women are valued because of their wealth-generating abilities, and they are most likely to generate wealth in rich, homogenous environments. Borgerhoff Mulder (1989) responded to White's view by demonstrating that he may have the causal sequence partially reversed. Her data show that although women may create wealth, polygynous men or men who become polygynous are initially wealthier than monogamous men. They have the bride price to marry more than one women and capital resources (e.g., land or cattle) to support an additional wife. Sororal polygyny, in contrast, is associated with economically simple societies of the New World where polygynous men are unusually productive (e.g., skilled hunters) or who have high status (e.g., headmen or powerful shamans). Yanomamö polygyny most resembles this form.

The Yanomamö present an interesting case in that polygyny rates are moderately high (see Low 1990 on measures of polygyny rates); yet capital holdings in economic resources (e.g., land or cattle) are nonexistent (Chagnon 1988, 1992), bride-price is absent (Chagnon 1979), and horticulture is not intensive (Hames 1989). The goal of this paper is to determine the role, if any, that economic factors (characteristic of many economically egalitarian tribal societies) play in Yanomamö polygyny. In brief, one wants to answer the following questions about economic performance by comparing polygynous and monogamous men and women: (1) Do polygynous men work more or more efficiently? (2) Do polygynous men have larger gardens? (3) Do polygynous women work less than monogamous women? (4) Do patterns of Yanomamö reciprocity show that polygynous families receive more food than monogamous families?

The assumption that underlies the above questions is that Yanomamö women who marry polygynously are potentially economically disadvantaged because one husband must support two wives and their offspring with the only economic resource he has, his own labor. This question is important in a species where biparental care is critical for reproductive success. One might argue that although polygynous women have to share the labor and resources of a single male they 


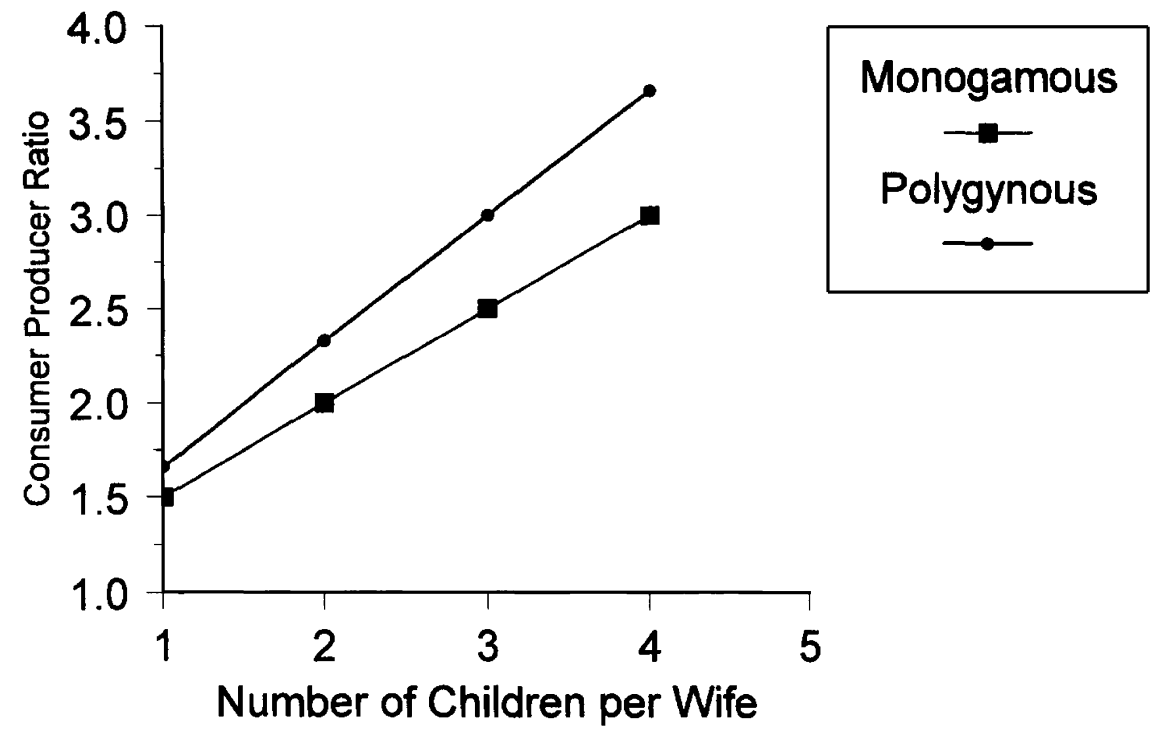

Figure 1. Consumer-to-producer ratios in polygynous and monogamous households.

only have to support a fraction of a male (one half, for example, if two women are married to the same man). Therefore, polygynously married women may not be worse off economically than monogamous women. One way to analyze these trade-offs is to compare consumer to producer ratios in polygynous and monogamous families. This measure is simply the number of consumers (the number of people in a household) per producer (the number of individuals who contribute to the household economy) (Sahlins 1972). Obviously, very young children are consumers, but they are not producers, and the age at which they become producers is an empirical question. ${ }^{1}$ For the Yanomamö this does not occur until about after the age of ten.

Figure 1 shows the effects of number of children per woman on the consumerto-producer ratios in monogamous and polygynous households. The model assumes that the number of children per woman under monogamous and polygynous unions are equal. ${ }^{2}$ With one child in the monogamous situation, there will be a ratio of two producers (husband and wife) per three consumers (husband, wife, and child) while under polygyny there will be three producers (husband and two wives) and five consumers (husband, two wives, and two children). The figure shows that polygynous households have higher consumer to producer ratios than monogamous households. Consequently, polygynous women are in house-

1. A productive adult counts as a single worker. A child is a fractional worker to the degree that he or she measures up to adult work levels. See Hames (1994: 123, Figure 3) for data on child labor time allocation relative to adult standards.

2. In fact, they are not. Polygynous households have a mean of 2.6 dependent children compared to 0.94 in monogamous households. Therefore, the comparison underestimates consumer-to-producer ratio in polygynous households because polygynous households have a ratio of 1.86 versus 1.47 for monogamous households. 
holds where they or their husbands must work more or more efficiently if they are to achieve the same standard of living compared to monogamous households. This result is largely determined by the fact that polygynous households have twice as many children as monogamous households. Whether or not polygynous households will have higher consumer to producer ratios will depend on fertility differentials between polygynous and monogamous women and the degree to which children make significant economic contributions to the household economy. ${ }^{3}$

\section{Sources of Economic Differentiation among the Yanomamö}

Yanomamö may differentiate themselves economically in terms of resources (goods) or labor (services) that they control. Among the Yanomamö resource differences are minute and do not serve to significantly differentiate individuals or households. Differences that do exist are found largely in the possession of nonindigenous goods. In lightly contacted villages, one household may have two good machetes, an ax, and several aluminum pots while the other may have one worn machete, no ax, and one pot. However, Yanomamö can normally borrow these labor-saving devices from co-villagers when needed. In contrast, villages with heavy mission contact typically contain several men, usually young, who work for missionaries and have superior wealth in terms of shotguns, outboard motors, canoes, and the like that give them added status. It is my impression that these young men tend to marry earlier, and, although they are monogamous because of missionary demands, they seem to have more extramarital sexual relations. ${ }^{4}$ It is not unreasonable to predict that in the near future mission villages may begin to develop patterns of economic stratification that would lead to a wealth-based system of polygyny or effective polygyny against a backdrop of socially imposed monogamy.

For traditional Yanomamö men, economic status is a function of work effort, skill, and the degree to which one can command the labor or resources of others. As a result, these are the factors that will be examined to determine whether they affect Yanomamö economic patterns in polygynous and monogamous households.

\section{Hypotheses Regarding Yanomamö Polygyny}

Chagnon's research on the Yanomamö (1979) demonstrates that female choice is strongly constrained by male domination and control of marriage transactions. He also notes the potential burden that polygyny places on males when they do not control extra material resources to support multiple wives. He suggests that

3. Cross-cultural data (see the Summary in Borgerhoff Mulder 1990) consistently show that polygynous women (junior wives in particular) have lower fertility than monogamous women. However, these findings have no clear implication on the quality of offspring produced or whether junior wives, for example, could have done better by marrying monogamously. For a more recent and comprehensive review of the literature, see Pebley and Wariara (1989).

4. See, for example, Holmberg's (1950) account of the effect that gaining a shotgun had on the sex life of a Siriono hunter. 
it is unlikely that such men work twice as efficiently or as hard as monogamous males; instead he proposes that polygynous men may have the ability to command the labor and resources of others. As I will show, data in this paper supports that interpretation.

For the sake of this analysis, I temporarily assume that some degree of female choice is operative in regard to the decisions women make about who they will marry or continue to be married to. This will allow one to more carefully consider the impact of polygyny on Yanomamö women. Even if female choice is absent among the Yanomamö, it is still useful to understand the comparative costs and benefits to women in polygynous and monogamous unions. I will return to the issue of female choice versus male control in Yanomamö marriage in the Discussion section.

If a Yanomamö woman chooses to become a co-wife, she should do so if it allows her to increase her reproductive success. Because I have no information on reproductive success of monogamous and polygynous women, I use indicators of potential enhancement of reproductive success. These are economic characteristics of males that would make them attractive because they possess attributes that would enhance a woman's fitness. For the Yanomamö, the following factors are likely critical male attributes in female mate selection: the ability to channel more food to wives and offspring, providing more care to offspring, or reducing wives' workload. If female choice in marriage were operative, one or more of the following would have to be true of polygynous males: (1) Polygynous males work more or work more efficiently ${ }^{5}$ than monogamous males. (2) Polygynous males provide more direct childcare than monogamous males. (3) Polygynous males have larger gardens than monogamous males. (4) Polygynous households receive more food resources from other households. ${ }^{6}$

If polygynous males possessed one or more of the four attributes listed above, polygynous women, compared to their monogamous sisters, may be attracted to polygyny because such women (1) work less than monogamous women, (2) allocate more time to childcare, or (3) they and/or their children have better diets.

Also there may be advantages of being a co-wife that are more or less independent of a husband's economic activities and instead correspond to interaction patterns among co-wives (Grossbard 1976; Irons 1983). For example, co-wife cooperation in economic tasks or childcare activities may lead to economies of scale, the consequences of which could lead to (1) reduced work loads or (2) more work accomplished in the same amount of time. As I will later detail, economies of scale may occur through co-wife cooperation, but one does not have to have a co-wife in order to cooperate.

5. Measures of efficiency (return per effort) in economic activities were not collected. It is unlikely that such measures would show much significant variation in gardening and gathering, but they may be important in fishing and certainly are important for hunting (Hames 1989).

6. In some societies the flow of services through garden labor exchange (Hames 1987; Hawkes 1983) is a way in which some households can subsidize others. Among the Yanomamö, garden labor exchange is uncommon. 
Finally, it is possible that being married to a high-status male could confer benefits on a woman's offspring that are not directly related to a husband's provisioning his family. Hill and Kaplan show that offspring of high-status Aché males receive more care and protection from other band members (Hill and Kaplan 1988). Whether these benefits (or others such as a father's assistance in marriage negotiations on behalf of his son) accrue to offspring of high-status Yanomamö males will be considered in the Discussion section.

\section{VILLAGES AND METHODS}

\section{Villages}

The data for this article was collected in 1986 and 1987 in the villages of Sheroanateri, Mishimishimaböwei-teri, and Mosuu-teri. ${ }^{7}$ At the time of the research, Sheroana had fissioned into two sections that I will refer to separately by the names of their headmen: Krihisiwä and Rakoiwä. These villages are separated from one another by a ten-minute walk. ${ }^{8}$ When members of both villages co-resided, they were collectively known as Sheronana-teri, the place name of a shallow stream (ca. 0.2-m depth) that serves as their main source of drinking water. They are still known by this name, but knowledgeable outsiders distinguish the location of each faction. Both are about a three- to four-day walk from the Salesian Mission at Platanal and a half-day's walk from the Orinoco River.

In contrast, the village of Bisaasi-teri (or Mosuu-teri) is located directly across the Orinoco River from the Salesian Mission at Mavaca, where it occupies the confluence of the Mavaca and Orinoco Rivers. Compared to the other villages in this study, it is highly acculturated (Chagnon 1992), although it is the most conservative of the mission villages. Nearly all school-age children irregularly attend the mission school, adults frequently trade with local missionaries, and several young adults are employed by the mission in a variety of tasks, ranging from elementary school teaching to various types of manual labor.

The village of Mishimishimaböwei is located in the headwaters of the Mavaca River. Although it is the most isolated of all villages in the sample (four- to fivedays' travel from the nearest mission), it has been the subject of extensive research (e.g., see Chagnon 1974 and references therein). During my time allocation study, approximately one half of the village was on trek (wayumö).

The sociodemographic attributes of Yanomamö villages under study are displayed in Table 1. ${ }^{9}$ The data presented on economic performance of polygynous and monogamous Yanomamö represent various subsets of the individuals rep-

7. Mosuu is historically a part of Bisaai and Sheroana part of Patanowa (see Chagnon 1992 for information on the history and politics of village movement and fissioning).

8. When a village fissions but each portion chooses to live nearby, this living arrangement is known as he borarawä. It occurs when within-village disputes are too intense for people to amicably co-reside but yet the threat of raids from common enemies is too great for them to separate far from one another (Chagnon 1992: 87).

9. Data presented here on marriages were collected by my colleague Napoleon Chagnon in the course of our joint fieldwork. 
Table 1. Sociodemographic Attributes of Yanomamö Villages in Study

\begin{tabular}{|c|c|c|c|c|c|c|}
\hline \multirow[b]{2}{*}{ Village } & \multicolumn{2}{|c|}{ Monogamous } & \multicolumn{2}{|c|}{ Polygynous } & \multirow{2}{*}{$\frac{\text { Polyandrous }}{\text { Male }}$} & \multirow[b]{2}{*}{ Total } \\
\hline & Male & Female & Male & Female & & \\
\hline Mishi. & 16 & 16 & 7 & 14 & 3 & 56 \\
\hline Krihisiwä & 8 & 8 & 4 & 8 & 1 & 29 \\
\hline Rakoiwä & 8 & 8 & 2 & 6 & 1 & 25 \\
\hline Mosuu & 20 & 20 & 4 & 8 & 0 & 52 \\
\hline
\end{tabular}

resented in Table 1. Their inclusion in subsequent analyses of economic performance depends on whether they were full-time residents or if they had recently returned from a long absence and had not either set up a working garden or were not present for a sufficient period of time for me to collect reliable economic data. Approximately $25 \%$ of all married men are married polygynously.

The existence of polyandrous marriages presents a special analytical problem and requires some comment. The Yanomamö word yedua means to "add to" or "combine with" and is used to refer to a male who has joined a household to share the wife or one of the wives of the resident male. ${ }^{10}$ In most cases it is a temporary state of affairs (cf. Equilior Garcia 1984: 85-86, who claims polyandrous marriages are long-term) and usually ends when the polyandrous male succeeds in gaining a wife of his own. In this study, all cases of polyandry occurred in the context of a polygynous marriage. In these situations, the senior male has sexual access to both wives, and the junior male has access to only one of the wives, which may be regulated by the senior male (Napoleon Chagnon, personal communication). Normally, the second male in the arrangement is a young, close relative (usually a brother).

The presence of another male in the household would reduce the consumerto-producer ratio and in most cases should be considered a separate marital form from monogamous and polygynous arrangements. In the data under consideration, there were five polygynous-polyandrous unions. I have excluded all polyandrous males from the analysis of labor time and garden size. Furthermore, I do not present garden size or exchange data on any of the households in the village of Mishimishimaböwei, where three of the five polygynous-polyandrous unions occur. The remaining two polygynous-polyandrous unions, one each in Krihisiwä and Rakiowä, are more sexual than economic. In one case the polyandrous male does not have a garden and lives with his parents. In the other case, the polyandrous male has the smallest garden in the village, maintains a separate hearth, and is a visitor to the village.

10. In some cases a monogamous male may share his wife. I have no data on the distribution of monogamous and polygynous forms of polyandry, but I suspect that the former (in areas where I have done research) is rarer than the latter. In this report all polyandrous arrangements involved a polygynous household. Early and Peters (1990: 40, 106$107,120)$ report relatively high rates of polyandrous unions for Yanomamö living in the Mujacai basin of Brazil, which Peters (Peters, 1982; Peters and Hunt 1975) attributes to a temporarily imbalanced sex ratio. There $25 \%$ of all births were from polyandrous unions. In the Mavaca area, where some of this research was conducted, Eguillor Garcia reports that $5.7 \%$ of all marriages are polyandrous and $3.4 \%$ polygynous-polyandrous (Eguillor Garcia 1984: 85). Finally, men generally regard polyandry as an inferior marital arrangement while women may view it positively. 


\section{Time Allocation}

Behavioral sampling occurred in January, February, and March, the middle of the dry season. ${ }^{11}$ During this time, the Yanomamö frequently trek (wayumö) or engage in long-distance hunting (heniyomou) in preparation for multi-village feasts (reahu). Indeed, during the behavior sampling period nearly all the able-bodied men in the villages of Krihisiwä, Rakoiwä, and Mishimishimaböwei engaged in overnight heniyomou hunting lasting from three to five days. Although I sampled behavior during these periods, heniyomou days have been deleted (for males and females) in the present analysis because most able-bodied men are expected to participate. Including these days would have reduced the variance in time allocation among all males.

All measures of time allocation were gained through scan sampling (Altmann 1974; Hames 1992b; Johnson 1975). At random hours of the day the behavior, location, time, and interaction of all individuals within the shabono (village) and its immediate environs were recorded. If an individual was absent from observation because he or she was in the forest hunting, gathering, gardening, or fishing, a knowledgeable informant provided preliminary information about the absent person's activity. Such information was corroborated when the absent person returned to the village. For the four villages, a total of 11,912 observations were recorded for an average of 48 observations per individual. Observations were recorded from 06:00 hours to 19:59 hours (a continuous period of 780 minutes or 13 hours), the typical time of rising in the morning and settling down to sleep in the evening. Thus, hours or minutes allocated to various activities may be estimated by multiplying the percentages in the tables and figures by 13 hours or 780 minutes.

\section{Food Sharing}

Data on food sharing was collected at the same time as data on time allocation (Hames 1992a). Following the method first described by Kaplan and Hill (1985a, 1985b), I recorded household food sharing in the following way: If in the course observing behavior an individual was eating, I identified the food consumed and asked who had produced the food. If it was garden food, I recorded the household garden in which it was produced, and if was a wild resource I asked who obtained it from forest or stream. ${ }^{12}$ Scan-based food exchange data

11. It could be argued that significant seasonal variation in time allocation could skew labor time results. However, there is no reason to believe that seasonal variation would affect monogamous and polygynous households differentially, and my initial time allocation research on the Yanomamö conducted in 1975-76 leads me to believe that although some kinds of activity have a seasonal component (i.e., garden clearing in November and December, a task dominated by men), the overall level of work throughout the year is relatively stable. Furthermore, garden size differences (presented below) between polygynous and monogamous males would be a good index for differential seasonal time allocation if there were any.

12. Like many other groups (see Marshall's 1961 work on the !Kung San), food exchanged by the Yanomamö may circulate through several households before it is actually consumed. The data I present simply distinguish own-household versus other-household sources of food consumed. Intervening linkages in exchange are documented elsewhere using a different method (Hames 1990). 
were collected from the villages of Mosuu, Rakoiwä, and Krihisiwä. Food exchange data was also collected from Mishimishimaböwei, but with a different, non-comparable method and therefore is not presented here (see Hames 1990 for details).

The first stage in analysis was to associate all consumers (i.e., eaters) and producers with their respective households (also, see below). Defining household membership in most cases was relatively simple. Households own a garden or gardens and usually consist of a monogamous or polygynous nuclear family of two and sometimes three generations. Classificatory complications arise in the case of newlyweds going through the process of clearing their own gardens and old widows or widowers beginning to merge with the households of their mature children as they abandon their own gardens. These complications were statistically rare, and in both examples ownership of a producing garden determined household membership.

The measures of household food exchange presented in Table 3 below are what I call outside consumption or exchange dependency. It is a measure of the proportion of food consumed by members of a domestic unit that was originally produced by other households. For example, 35\% means that 35\% of all food consumed by household members was produced by other households and the balance of $65 \%$ indicates the percentage of food consumed by household members that was produced by themselves.

\section{Garden Size}

All gardens in the villages of Mosuu, Krihisiwä, and Rakiowä were measured by making a center line through the length of a garden and then measuring $180^{\circ}$ across the center line at 8 -meter intervals. These measures were transferred to graph paper and scaled, lines at the edges were connected, and the area in square meters was estimated. A total of 40 gardens were measured, but only 30 are included for analysis. Because the goal of analysis is to compare the gardens of monogamous and polygynous men, 10 gardens were excluded because they belonged to widows (2), unmarried men (2), newly married men with no children who were still performing bride service (4), or polyandrous men (2).

\section{Units of Comparison}

Defining units of comparison in the analysis of polygynous and monogamous families is problematic. The Yanomamö recognize what I would refer to as households as independent economic units. These units have their own gardens and are expected to be able to supply all their subsistence needs. At the core of a household is a monogamous or polygynous family consisting of a husband and wife or wives and their offspring. Most households conform to this simple structure. However, in some cases, core households may contain other families such as elderly couples who have attached themselves to a son's household, widows and widowers, or young males who may be brothers to the core male. 


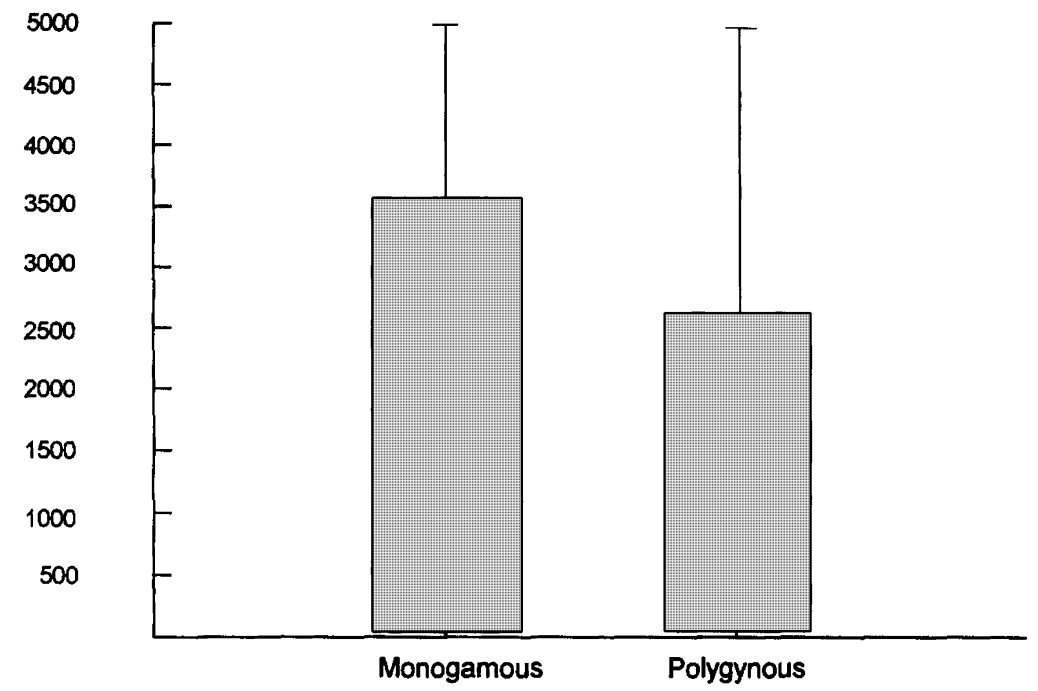

Household Type

Figure 2. Garden size of polygynous and monogamous households.

\section{RESULTS}

\section{Garden Size}

Table 2 reveals that in two (Krihisiwä and Mosuu) of the three villages the households of monogamous males have larger gardens than the households of polygynous males, in one village (Rakoiwä) polygynous males have larger gardens, and in all three villages combined, monogamous males make larger gardens than polygynous males. In all comparisons, the differences are not statistically significant (Figure 2).

It is worth noting that Chagnon (1992) has stated that village headmen tend to have the largest gardens in the village because of their responsibility for hosting village feasts (reahu). In the three villages sampled, the headmen of Rakoiwä and Krihisiwä have the largest gardens in their respective villages, while the aged headman of Mosuu-teri has one of the smallest gardens (at $\left.1263 \mathrm{~m}^{2}\right){ }^{13}$

\section{Labor Time Allocation}

In a comparison of labor time allocation, the unit of analysis becomes individuals instead of households, as was shown for garden size (above) and food sharing (below). The goal is to compare the labor efforts of monogamous and

13. Although the aged headman of Mosuu-teri has one of the smallest gardens, he reputedly had "headman sized" gardens throughout his long tenure as headman. In addition, he can rely on close kin and in-laws to supply plantains for village feasts. 
Table 2. Marriage Status by Garden Land Under Cultivation by Village

\begin{tabular}{lccc}
\hline & $N$ & Mean $\mathrm{m}^{2}$ & SD \\
\hline All villages & & & \\
$\quad$ Monogamous households & 19 & 2857 & 1510 \\
$\quad$ Polygynous households & 11 & 2784 & 2497 \\
$\begin{array}{l}\text { Village of Krihisiwä } \\
\quad \text { Monogamous households }\end{array}$ & 4 & 2355 & 1743 \\
$\quad$ Polygynous households & 4 & 2185 & 1107 \\
$\quad$ Village of Rakoiwä & 3 & 4199 & 3335 \\
$\quad$ Polygynous households & 5 & 2955 & 1777 \\
$\quad$ Monogamous households & & & 3064 \\
$\quad$ Village of Mosuu-teri & 4 & 2322 & 1347 \\
$\quad \begin{array}{l}\text { Polygynous households } \\
\text { Monogamous households }\end{array}$ & 10 & 3028 & \\
\hline
\end{tabular}

polygynous men and women. Figures 3 and 4 show that there are no statistically significant differences in labor time allocation in relation to marital status for men or women. Although there is a significant inverted U-shaped (quadratic) relationship between labor time and age (peaking at age 38) for men, polygynous men (mean age 43) are not significantly older than monogamous men (mean age 38).

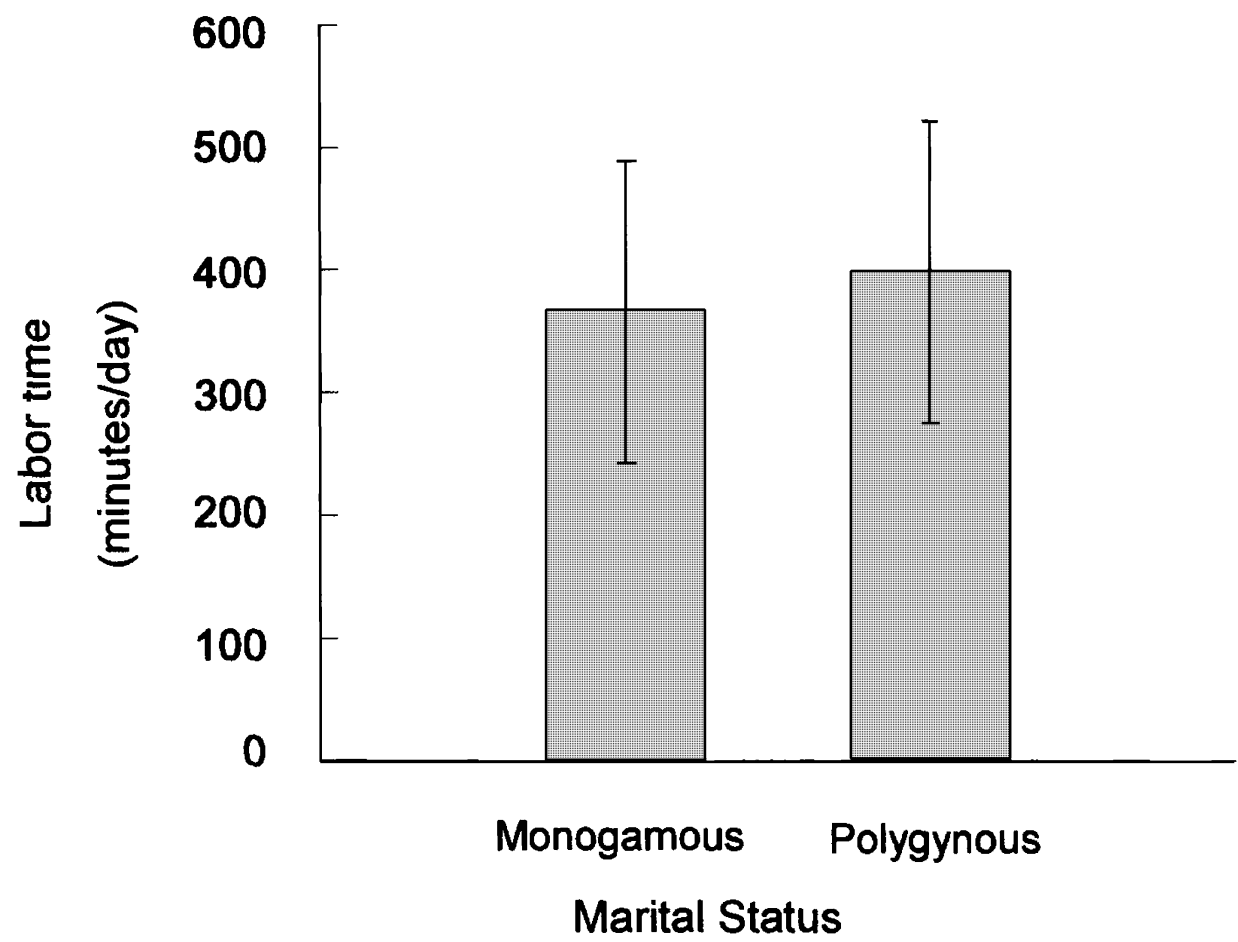

Figure 3. Male labor time by marital status. 


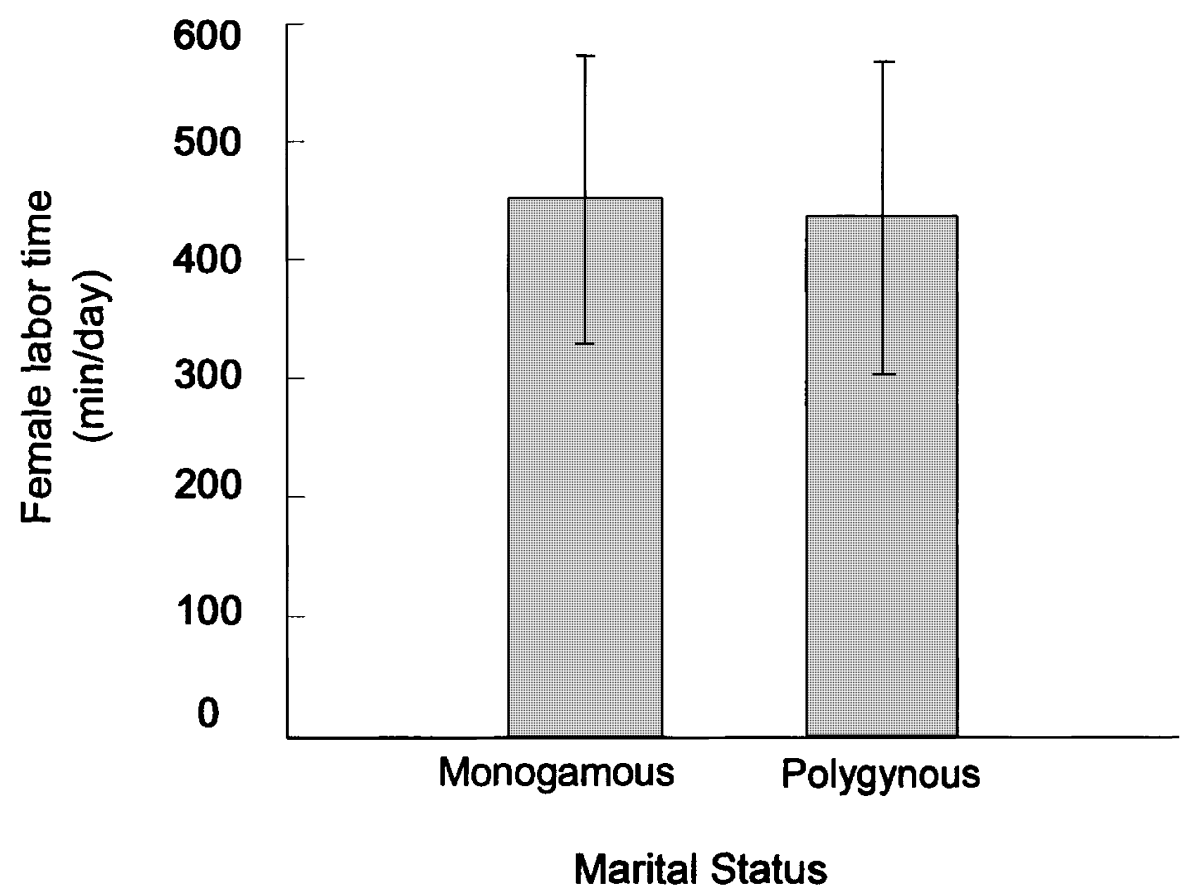

Figure 4. Female labor time by marital status.

\section{Food Sharing}

Yanomamö food sharing is intense and occurs to varying degrees for all food types (Hames 1990). As described in the Methods section, data on food sharing were calculated using a behavioral observation technique. The data below indicate the proportion of food observed being consumed for each food type that was produced outside of the eater's household or domestic unit. For example, in Table $3,50 \%$ of the garden food consumed by polygynous household members was given to them by other households while the corresponding figure for monogamous household members was $27 \%$.

As Table 3 and Figure 5 reveal, in each food category and for all combined, with the exception of gathered foods, polygynous household members gained a larger fraction of their food from other households. However, these differences are statistically significant only for garden foods ( $p=.01, T$-test, two-tailed) and for all food exchanges combined ( $p=.03, T$-test). The statistical significance of garden food exchange takes on added weight when one realizes that garden food supplies $75 \%$ and more of all food calories consumed by Yanomamö (Hames 1989).

\section{Childcare and Marital Status}

Previously, I (Hames 1992b) showed labor time of polygynous men was never correlated with the number of their dependent children, and it was only occasionally correlated for monogamous males. That is, male work load does not normally 
Table 3. Food Sharing (Outside Food) by Food Type for Monograms and Polygynous Households

\begin{tabular}{|c|c|c|c|}
\hline Household type & $N$ & Mean & SD \\
\hline \multicolumn{4}{|l|}{ Fishing } \\
\hline Polygynous & 11 & 40.90 & 29.48 \\
\hline $\begin{array}{l}\text { Monogamous } \\
\quad \text { significance } p=.094\end{array}$ & 18 & 21.27 & 28.72 \\
\hline \multicolumn{4}{|l|}{ Gardening } \\
\hline Polygynous & 11 & 50.29 & 21.38 \\
\hline $\begin{array}{l}\text { Monogamous } \\
\quad \text { significance } p=.01\end{array}$ & 18 & 27.64 & 20.84 \\
\hline \multicolumn{4}{|l|}{ Gathering } \\
\hline Polygynous & 11 & 26.20 & 38.17 \\
\hline $\begin{array}{l}\text { Monogamous } \\
\text { significance } p=.77\end{array}$ & 18 & 30.09 & 29.82 \\
\hline \multicolumn{4}{|l|}{ Game } \\
\hline Polygynous & 11 & 65.91 & 39.42 \\
\hline $\begin{array}{l}\text { Monogamous } \\
\quad \text { significance } p=.39\end{array}$ & 18 & 52.67 & 42.95 \\
\hline \multicolumn{4}{|l|}{ All foods } \\
\hline Polygynous & 11 & 44.68 & 17.46 \\
\hline $\begin{array}{l}\text { Monogamous } \\
\quad \text { significance } p=.03\end{array}$ & 18 & 29.08 & 17.90 \\
\hline
\end{tabular}

increase with the number of dependent ${ }^{14}$ children, and this is especially true of polygynous males. Still, it is possible that polygynous males may provide more direct childcare (i.e., holding, carrying, feeding, etc.) for children or that wives of polygynous males might be able to provide more direct care for their children. The problem with this sort of analysis is that the amount of direct parental investment in offspring is extremely sensitive to the age of a dependent child (Hames 1992b: 90, Figure 1). This makes statistical analysis impossible given current sample size. Furthermore, because polygynous men or women work the same amount of time as monogamous men or women (see above) it is doubtful that they would have any more "spare" time than monogamous parents to engage in direct childcare. With these caveats in mind, the following statistical point is made: Polygynous men have an average of 2.6 dependent children in their families compared to 0.94 for monogamous men, yet they spend fewer minutes per day (4.72) in direct childcare compared to monogamous men (6.60). However, differences in number of children and time allocated to care by marriage type are not statistically significant. ${ }^{15}$

Analysis of time allocation to direct childcare by monogamous and polygynous women suffer from the same problems as it does for men. Although polygynous women had more dependent children and expectedly allocated more time to childcare then monogamous women, neither of these differences were statisti-

14. Dependent children are all children less than 10 years of age. This boundary is used because children begin to make major economic contributions to their own and family subsistence at 10 years of age.

15. These differences, if reliable, parallel Hewlett's (1988) findings that polygynous Efe Pygmy men spend less time in childcare than monogamous men. 


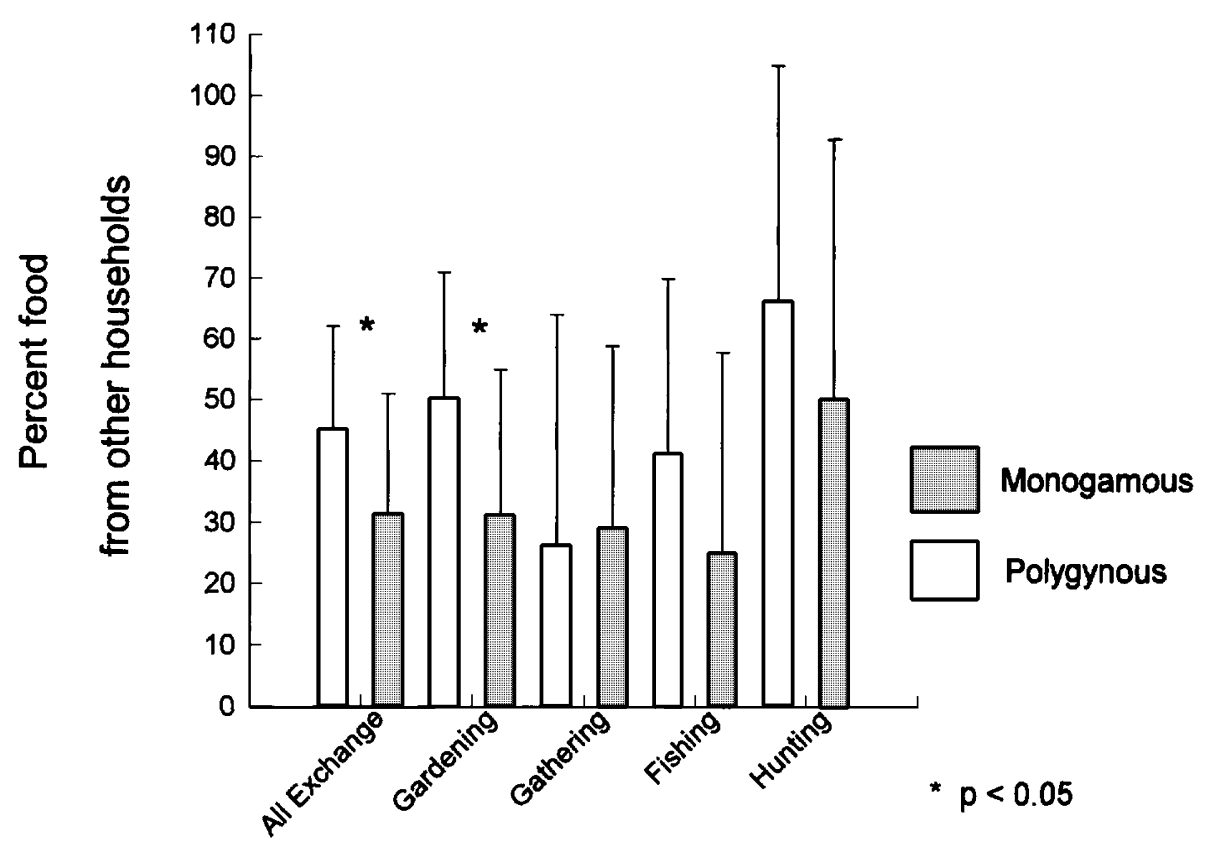

Figure 5. Yanomamö exchange by household type.

cally significant. However, it is possible that children in polygynous families receive more care from nonbiological parents than children in monogamous families (e.g., Borgerhoff Mulder and Milton 1985)

\section{DISCUSSION}

The economic benefits and costs that accrue to polygynously married Yanomamö women is the central focus of this analysis. Given that polygynous Yanomamö men do not possess or control material resources commonly found in societies with resource defense polygyny (Borgerhoff Mulder 1990), one is led to suspect that polygyny compared to monogamy would be a costly reproductive choice for women because they must divide the economic efforts of a single husband and thus live in a household with a higher consumer-to-producer ratio. This question naturally led to a comparison of labor time allocation, garden size, and food exchange patterns, the results of which I discuss immediately below.

Labor time allocation statistics for monogamous and polygynous Yanomamö reveal that polygynous men do not work more than monogamous men and that polygynous women do not work more than monogamous women. While it is clear that polygynous women do not pay a penalty by having an increased work load, the result is puzzling when we know that polygynous families have a higher adult-to-consumer-to-producer ratio (1.86:1 and 1.5:1, for polygynous and monogamous families, respectively) and if we assume that the basic economic needs of each family are to be met solely by their own personnel. 
It is possible that polygynous Yanomamö men work more efficiently than monogamous men, leading them to get more work done in the same amount of time. Such differences would only emerge in highly skilled activities such as hunting. My previous research among a different group of Yanomamö (Hames, 1989) indicates that the best hunters hunt two to three times more efficiently (measured in kilograms of game per hour of hunting) than average hunters. However, there is a negative correlation between hunting efficiency and hunting time allocation such that good hunters hunt fewer hours per day than poor hunters (Hames 1992a: 214216). A possible reason that good hunters hunt less is the presumption that successful hunters share game with co-villagers. Because there is no apparent ${ }^{16}$ compensation for sharing kills, there is little incentive for efficient hunters to hunt as much as poor hunters. Therefore, even if polygynous males were more efficient hunters, this benefit is not reaped by their wives or offspring (Hames 1990) $1{ }^{17}$ Other productive activities include fishing, gardening, and gathering. While these activities require skill and expertise to be accomplished efficiently, there is little reason to suspect that there is great variation in skill among adult men or women that would lead to differences in the rates at which these tasks are accomplished.

It is possible that economies of scale between co-wives would make polygyny economically attractive and thus reduce the costs of dividing a husband's labor. Commonly, fishing, gathering, and gardening are done in groups. With the exception of poison fishing, none of the productive activities require cooperation, but it is highly likely that economies of scale are realized by coordinating different tasks in a common activity. ${ }^{18}$ Nevertheless, monogamously married women frequently cooperate with each other and with polygynously married women. Although I have not yet quantified the frequency at which women work in groups and their sizes, it is my strong impression that adult women very rarely leave the village without another adult as a companion. ${ }^{19}$

Grossbard (1976) shows that cooperation in childcare is an important benefit of being co-wife. Assistance in childcare, regardless of its source, would be important to a Yanomamö woman for a number of reasons. Yanomamö women spend an enormous amount of time in direct childcare (nursing, feeding, carrying, and

16. It is entirely possible, as M. Borgerhoff Mulder points out to me (personal communication), that productive hunters may exchange game for other food resources such as garden produce. If this were true, then we might predict a kind of village-wide or extra-household division of labor where some families may be specialized in garden foods while others in hunting. While this could occur, it would be difficult for me to conclusively evaluate such a pattern with current data.

17. This situation contrasts sharply with groups such as the Aché, where good hunters share widely and their households gain fitness-enhancing benefits (Hames 1990).

18. Economies of scale may be crucial for women with highly dependent offspring. Women carry infants in slings everywhere they go. When doing active or dangerous work (e.g., chopping firewood), the infant is usually handed to a companion for safekeeping.

19. Furthermore, they frequently labor in groups of three or more that often contain men. Men accompany women sometimes to help (e.g., felling fruit trees), for fear that women may be abducted by raiders, or because a sexually jealous husband may believe his wife is sneaking off alone to tryst with another male. 


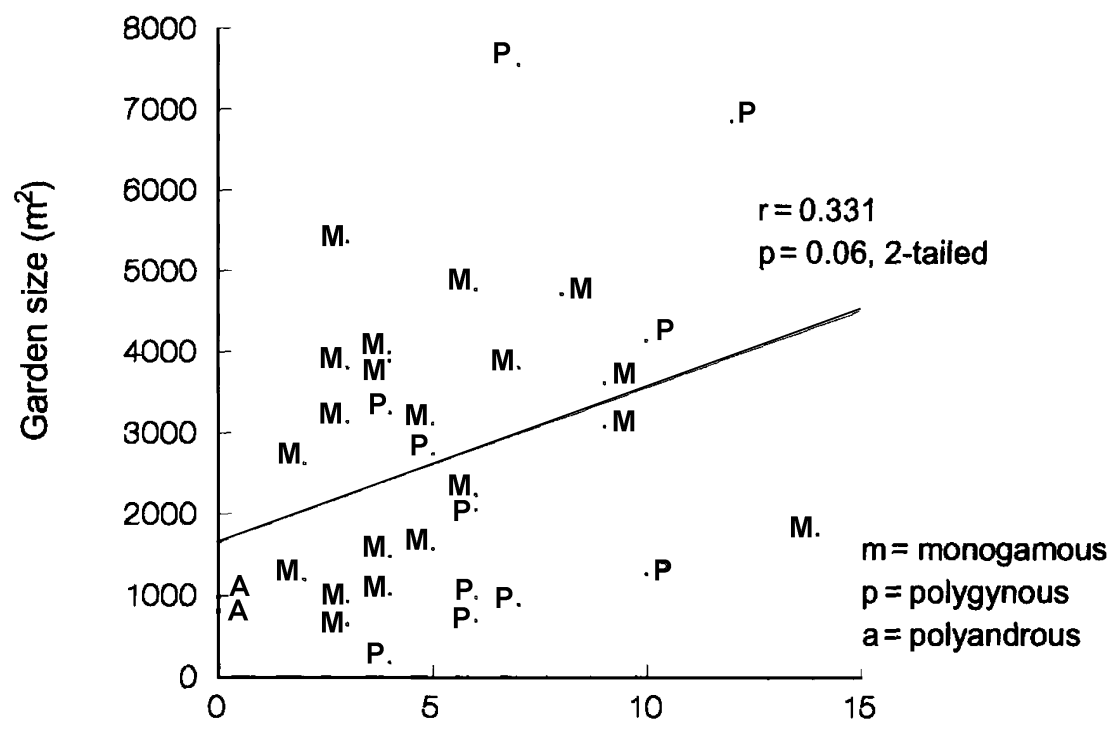

Family size

Figure 6. Garden size as a function of family size for monogamous and polygynous families.

holding) and indirect care through proximity maintenance (Hames 1992b). For example, the mother of a one-year-old child spends approximately $70 \%$ of her time within one meter of that child (Hames 1992b: 102).

In many ways a nursing child is a virtual appendage of its mother. The child goes wherever the mother goes, and nursing women actually work less than nonnursing women (Hames 1992b: 100, Table 4 and Figure 7). High-quality childcare is especially important for the Yanomamö, given that infant mortality rates range from 14\% (Early and Peters 1990) to 33\% (Melancon 1982) and that high-quality childcare is the most significant way in which a mother can protect a child from sources of morbidity and mortality in the Yanomamö environment. As mentioned earlier, the small sample size of young children and dramatic shifts in agerelated changes in care received by young children (Hames 1992b) precludes a comparison of total amount of care received by children of monogamous and polygynous mothers.

It is surprising that polygynous men do not make gardens significantly larger than monogamous men for the simple reason that, on average, polygynous men have significantly ( $t$-test, $p<.01$, two-tailed) larger families (8.6 people) than monogamous men (5.0 people) and there is a positive correlation $(r=0.33, p=.03$ one-tailed, see Figure 6) between garden land under cultivation and family size. A hypothesized positive correlation between family size and garden land under cultivation assumes that each family unit is primarily responsible for supplying its own subsistence needs. Given the amount of food exchange between Yanomamö households, this assumption may not be warranted. Furthermore, even if such an assumption were reasonable, family size only explains about $11 \%$ of the variance in garden size. 
The only significant economic difference that emerges between monogamous and polygynous households is that polygynous households received more food resources from other households. Therefore, one may conclude that the costs of sharing a husband who works no harder or efficiently than a monogamous husband and who does not have a larger garden than average may be compensated for receiving more food resources through household food exchanges. It may also explain why polygynous women do not work more than monogamous women. Whether this degree of compensation is great enough to offset the cost of sharing a husband cannot be unequivocally known with currently available data. Nevertheless, I suspect that direct subsidization of households through the food exchange system is sufficient to obviate the negative economic effects of high consumer-toproducer ratios in polygynous families. One way of evaluating the effect of subsidization would be to predict that the nutritional status of polygynous households is either the same or better than that of monogamous households.

The economic data presented do not show why Yanomamö women find polygynous men attractive, but they do suggest that it is not economically inferior to monogamy. The major constraint on female choice is that Yanomamö men make decisions about marriage. Chagnon's extensive and detailed analyses of Yanomamö marriages (e.g., 1979) shows that Yanomamö men use their sisters and daughters to acquire wives in exchange from other men who do the same. In effect, the Yanomamö reflect Levi Strauss's definition of marriage in egalitarian society as the exchange of women between groups of men (Levi Strauss 1949). More recently, Chagnon (1989: 31-35) explicitly considers the issue of female choice for the Yanomamö). He notes a number of factors that point both to male coercion and to female choice.

In many ways subsidization of polygynous households is similar to the findings of Betzig (1988) for a chiefdom on the island of Ifaluk. There she found that chiefs and other high-status individuals received more food from other households than they gave (1988: 52-54). She also found that chiefs worked less than commoners. The simplest interpretation of this pattern is that high-status households are being subsidized by low-status households. In the case of the Ifalukese, the pattern of subsidization of chiefly households appears to be built into their system of hereditary inequality (Betzig 1988: 60).

In contrast, the Yanomamö are a classic egalitarian society where status is achieved and not heritable, but their patterns of resource distribution resemble what is found in a system of hereditary inequality. The question we must ask of the Yanomamö is, Why are polygynous households economically subsidized by monogamous households? To answer this question we must deal with the question of status achievement. In egalitarian societies high status is achieved (and not ascribed) in a variety of ways dependent on how individuals measure up to local culture standards (Irons 1979). Among the Yanomamö, the main avenue for achievement of high status is through political leadership (Chagnon 1988, 1992). Effective political leaders represent the interests of their kin and co-villagers through political negotiations and, as is often necessary, through force of arms in dueling and raiding. As a result of this latter dimension of political leadership, high-status males are very likely to have killed an enemy and become an unokai 
or man killer. Chagnon (1988) has shown that unokais are much more likely to be polygynous than non-unokais. This relationship may help us to understand the economic subsidization of polygynous households: Leaders are rewarded for expending effort and risking their lives in the political arena with polygyny and the economic support of their households.

This answer still leaves us with the question of what benefits, if any, accrue to a woman who becomes a co-wife to a high-status male. At this point I can only suggest some hypotheses to investigate. It may be the case that high-status males are better able to ensure that their sons marry earlier in a milieu of high malemale competition over mates. Or, the economic benefits (through household subsidization) of becoming a co-wife are superior to the alternative of marrying a single male. These hypotheses could be investigated with quantitative data on marital success of children born to polygynous women or nutritional status of offspring in polygynous and monogamous families.

I thank Napoleon Chagnon for his invaluable assistance in identification of household composition and marital patterns in our joint field work on the Yanomamö. I also thank Napoleon Chagnon, Monique Borgerhoff Mulder, Carol Ember, and Kim Hill for their useful comments on the manuscript. This paper was originally presented at the fifth annual HBES meetings in Ann Arbor (June 18, 1993) in a session organized by Eric Smith entitled "Evolutionary Ecology, I." Funding for the collection of the data was provided by the National Science Foundation (BSN 8411669).

\section{REFERENCES}

Altmann, J. The observational study of behavior. Behaviour 48:1-41, 1974.

Betzig, L. Despotism and Differential Reproduction: A Darwinian View of History, Hawthorne, NY: Aldine, 1986.

Betzig, L, Redistribution: Equity or exploitation? In Human Reproductive Behavior, L. Betzig, M. Borgerhoff Mulder, and P. Turke, eds. Cambridge: Cambridge University Press, 1988, pp. 45-60.

Borgerhoff Mulder, M. Polygyny threshold: A Kipsigis case study. National Geographic Research 21:33-37, 1985.

Borgerhoff Mulder, M. Resource and reproduction in women with an example from the Kipsigis. Journal of Zoology, 1987.

Borgerhoff Mulder, M, The relevance of the polygyny threshold model to humans. In Mating Patterns, C. Mascie-Taylor and J. Boyce, eds. Cambridge: Cambridge University Press, 1988, pp. 84- 102.

Borgerhoff Mulder, M. Polygyny and the extent of women's contribution to subsistence: A reply to White. American Anthropologist 91: 178-180, 1989.

Borgerhoff Mulder, M. Kipsigis women's preferences for wealthy men: Evidence for female choice in mammals? Behavioral Ecology and Sociobiology 27:255-264, 1990.

Borgerhoff Mulder, M. and Milton, M. Factors affecting infant care among the Kipsigis. Journal of Anthropological Research 4:231-262, 1985.

Boserup, E. Women's Role in Economic Development, New York: St. Martin's, 1970.

Chagnon, N. Studying the Yanomamo. New York: Holt, Rinehart and Winston, 1974. 
Chagnon, N. Is reproductive success equal in egalitarian society? In Evolutionary Biology and Human Social Behavior, M. Chagnon and W. Irons, eds. North Scituate, MA: Duxbury Press, 1979, pp. 374-401.

Chagnon, N. Life histories, blood revenge, and warfare in a tribal population. Science 239:985-992, 1988.

Chagnon, N. Nepotism and the Great Transformation. Paper presented at the 1st HBES Annual Meeting, 1989.

Chagnon, N. Yanomamo: The Fierce People, 4th ed. New York: Harcourt Brace Jovanovich, 1992.

Early, J., and Peters, J. The Population Dynamics of the Mucajai Yanomama, New York: Academic Press, 1990.

Eguillor Garcia, M. I. Yopo, Shamanes y Hekura, Caracas, Venezuela: Libreria Editorial Salesiana, 1984.

Grossbard, A. An economic analysis of polygyny. Current Anthropology 17:701-707, 1976.

Grossbard, A. The economics of polygamy. In Research in Population Economics, Vol. 2, J. L. Simon, and J. Da Vanzo, eds. Greenwich, CT: JAI Press, 1980, pp. 321-350.

Hames, R. Relatedness and garden labor exchange among the Ye'kwana. Ethology and Sociobiology 8:354-392, 1987.

Hames, R. Time, efficiency, and fitness in the Amazonian protein quest. Research in Economic Anthropology 11:43-85, 1989.

Hames, R. Sharing among the Yanomamö, the effects of risk, In Risk and Uncertainty in Tribal and Peasant Economies, E. Cashdan, ed. Boulder, CO: Westview, 1990, pp. 89-105.

Hames, R. Time allocation. In Evolutionary Ecology and Human Behavior, E. A. Smith and B. Winterhalder, ed. Chicago: Aldine de Gruyter, 1992a, pp. 203-236.

Hames, R. Variation in paternal care among the Yanomamö. In The Father's Role: Cultural and Evolutionary Perspectives, B. Hewlett, ed. Chicago: Aldine de Gruyter, 1992b, pp. 85-110.

Hames, R. Yanomamö, varying adaptations of foraging horticulturalists. In Ethnographic Profiles: Original Readings, M. Ember, C. Ember, and B. Levinson, eds. New Haven, CT: HRAF Press, 1994.

Hawkes, K. Kin selection and culture. American Ethnologist 10:345-363, 1983.

Hartung, J. Polygyny and the inheritance of wealth. Current Anthropology 23:1-12, 1982.

Hewlett, B. Sexual selection and paternal investment among Aka Pygmies. In Human Reproductive Behavior: A Darwinian Perspective, L. Betzig, M. Borgerhoff Mulder, and P. Turke, eds. Cambridge: Cambridge University Press, 1988, pp. 263-276.

Hill, K., and Kaplan, H. Tradeoffs in male and female reproductive strategies among the Ache: part 1. In Human Reproductive Behavior: A Darwinian Perspective, L. Betzig, M. Borgerhoff Mulder, and P. Turke, eds. Cambridge: Cambridge University Press, 1988, pp. 277-289.

Holmberg, A. Nomads of the Long Bow: The Siriono of Eastern Bolivia, Washington, DC: Smithsonian Institution, 1950.

Irons, W. Cultural and biological success. In Evolutionary Biology and Human Social Behavior, N. Chagnon and W. Irons, eds. North Scituate, MA: Duxbury Press, 1979, pp. 67-89.

Irons W. Human female reproductive strategies. In Social Behavior of Female Vertebrates, S. Wasser and M. Waterhouse, eds. New York: Academic Press, 1983, pp. 169-213.

Johnson, A. Time allocation in a Machiguenga community. Ethnology 14:30 I-310, 1975. 
Kaplan, H., and Hill, K. Food sharing among Ache foragers: Tests of explanatory hypotheses. Current Anthropology 26:223-245, 1985a.

Kaplan, H., and Hill, K. Hunting ability and reproductive success among male Ache foragers: Preliminary results. Current Anthropology 26:131-133, 1985b.

Levi Strauss, C. The Elementary Structures of Kinship, Boston: Beacon Press, 1949 [1969].

Low, B. Marriage, systems and pathogen stress in human societies. American Zoology 30:325-339, 1990.

Marshall, L. Sharing, talking, and giving: Relief of social tensions among the !Kung bushmen. Africa 29:335-365, 1961.

Melancon, T. Marriage and Reproduction among the Yanomamo of Venezuela. Unpublished doctorate dissertation, Pennsylvania State University, 1982.

Murdock, G. P. Social Structure, New York: The Macmillan Company, 1949.

Pebley, A., and Wariara, M. Polygyny and fertility in sub-Saharan Africa. In Reproduction and Social Organization in Sub-Saharan Africa, Ron J. Lesthaeghe, ed. Pp. 120-145. Berkeley: University of California Press, 1989.

Peters, J. F. Polyandry among the Yanomama revisited. Journal of Comparative Family Studies 13:89-95, 1982.

Peters, J. F., and Hunt, C. L. Polyandry among the Yanomama Shirishana. Journal of Comparative Family Studies 6:197-207, 1975.

Sahlins, M. Stone Age Economics. Chicago: Aldine, 1972.

Smith, E. A. Human adaptation and energetic efficiency. Human Ecology 7:53-74, 1979.

White, D. Rethinking polygyny. Current Anthropology 29:529-571, 1988.

White, D., and Burton, M. Causes of polygyny: Ecology, economy, kinship and warfare. American Anthropologist 90:311-322, 1988. 